\title{
Investigation of High School Students' Environmental Attitudes in Terms of Some Demographic Variables
}

\author{
Nergiz Koruoglu' ${ }^{1}$ Ilker Ugulu ${ }^{2}$, Nurettin Yorek ${ }^{2}$ \\ ${ }^{1}$ Balikesir Albay C. Tayyar-Nuran Oguz High School, Balikesir, Turkey \\ ${ }^{2}$ Faculty of Education, Dokuz Eylul University, Izmir, Turkey \\ Email: nurettin.yorek@deu.edu.tr
}

Received 25 August 2015; accepted 9 October 2015; published 12 October 2015

Copyright (C) 2015 by authors and Scientific Research Publishing Inc.

This work is licensed under the Creative Commons Attribution International License (CC BY). http://creativecommons.org/licenses/by/4.0/

(c) (i) Open Access

\begin{abstract}
Studying individuals and students' attitudes towards environment and factors affecting students to be responsible individuals towards their environment may provide help towards the solution of environmental problems. In this study, it is aimed to evaluate environmental attitudes of high school students in terms of some variables. The sample of the study consists of $\mathbf{3 3 0}$ participants of whom 145 are male and 185 are female having studied in a High School in Balikesir (in western Turkey). In the study, as a means of data collection, Environmental Attitude Scale (EAS) and the personal information form have been used. The EAS which consists of 35 items is composed of 4 sub-dimensions as "Environmental awareness", "Attitude toward recovery", "Attitude toward recycling" and "Environmental consciousness and behavior". According to the findings, considering the analysis of the EAS, statistically a considerable difference was reached between the sub-dimensions of the EAS and the gender, grade and parent education level variables. However, a considerable difference was not found between the branch of students and some sub-dimensions of the EAS.
\end{abstract}

\section{Keywords}

Environmental Education, Environment, Attitude, Biology, High School

\section{Introduction}

It has always been an issue of debate that problems rising from the environment adaptation efforts of humankind to her own benefits, may cause rising of bigger problems in the future. Planet earth may face with huge disasters

*Corresponding author. 
unless national and international authorities pay necessary attention to environmental problems and prepare short and long term plans and encourage populations to adopt such plans, unless people behave due to their old habits and continue to use fossil fuels and petrochemicals which are composed of such fuels and pesticides as much as they want; unless they do not create new and more forests in place of those which were already destroyed; they consider environment as priority in technical developments, unless global warming continues and ozone hole continues to grow (Gunduz, 2004).

There are several and intense studies aiming to protect the balance and to provide sustainability of nature. But education is this area is necessary in order to understand the environmental problems and make meaningful contribution to the solutions of problems. In other words, education is essential for providing information and awareness to society on environment, to create meaningful change of behaviors in positive and sensitive direction and recovery what had been lost before. Thus, it may be possible to create an environmentally friendly society and to save money and time while solving the problems (Uzun \& Saglam, 2006).

Increasing awareness in societies comes together with protection of environment. Thus education on environment should be given widely. In recent years, in accordance with environmental problems became one of top issues of whole world, environmental education has become to be considered as individual and social need. Aim of all efforts to protect environment, to prevent environmental pollution and to develop environment is to create comfortable, peaceful and healthy environment for people. In order to reach success in efforts for studies done in the area of environment, youth should be considered as top priority. It is very important to give education to youth to help them define environmental problems, gather necessary information on the subject and to help them give right decision within the scope of this information (Ugulu, 2011).

Many studies on environment, environmental concepts and problems prove that, level of information of students on this subject is not sufficient, they are far from defining environmental concepts properly and they do not recognize environmental problems precisely (Ak, 2008; Altın, 2001; Bahar, 2000; Erol, 2005; Ugulu et al., 2008; Ugulu, 2011; Ugulu \& Erkol, 2013; Y1lmaz et al., 2002).

Environmental education is a process in which individuals not only gain information, awareness and skills, but also they gain the ability to be determined on taking actions in order to solve problems (Erol \& Gezer, 2006). The real purpose of environmental education is to bring sensitivity to individual on environmental issues and to develop a critical point of view in interaction with environment and leaving clean and healthy environment to coming generations (Dogan, 1997). With the environmental education, it is also aimed that individuals can define their own position in ecological balance, develop ideas about how to live in harmony with planet and to gain necessary skills for effective and responsible contribution (Geray, 1995).

Irresponsible environmental behaviors are the main causes of many environment problems. Without a doubt, one of the main dimensions that affect these behaviors is the attitude (Bradley et al., 1999). One can talk about several effects in the formation of attitudes. Individual is under the effect of formal education institutions and informal education societies. For providing positive attitude development of students in favor of protecting environment, environmental problems should be undertaken on problem basis. Thus, students are encouraged to see the subject as a problem, to gather information about the subject, to monitor and analyze the natural environment and to develop skills about the ability to decide on environmental issues. Addition to this, it is clearly defined that issue like reading books about environment, creating games on the environmental issues, giving education on art, making outdoor lectures, designing playgrounds properly and creating models have great importance (Dincer, 1999). Greater the importance given by the mass media on environmental issues, more people will gain awareness about environment. It is only possible if mass media would not only come up with issues such as disasters like flood but analyze issues deeply; seek solutions (Yumlu, 1998). Attitude scale applied in this study about environment, will provide information about the effects of education secondary students take on environment on their attitudes towards environment. Besides, effects of sections they are studying, gender and family education on environmental attitudes are also evaluated in this study.

\section{The Aim of the Study}

The aim of this study is to determine the environmental attitudes of high school students. Furthermore, having information about the relation between attitudes of students and grades and branches they take education and having a general view on productivity and efficiency of environmental education are among this study's aims. From demographic point of view, it is also aimed to determine whether there has been a relation between gender, 
education of families and environmental attitudes of students.

\section{Method}

\subsection{Model of Study}

In this study, environmental attitudes of $9,10,11$ and $12^{\text {th }}$ grades of high school students are tried to be determined. Within the scope of this aim, the study is executed with relational screening model. Relational screening models are models to determine existence and/or degree of covariance of two or more variables. Variables of which covariance are examined are symbolized but this symbolization must allow relational analysis. In the screening models, current situations and conditions are tried to be protected as they have originally been (Karasar, 2005).

In this study, "Environmental attitude scale" points are taken into account as dependent variable. In this study, data gathered through screening method are compared due to genders of students, branches they take education at and their parents' educational status. Finally, an assessment has been made based on these variables.

\subsection{Working Group}

Working group of the study is $9,10,11$ and $12^{\text {th }}$ grade students of Balikesir Albay Cafer Tayyar-Nuran Oguz Anadolu High School (in Balikesir, Turkey). There are total 330 students in working group, 185 of which are female and 145 of them are male. 115 of these students attend to sciences-mathematics, 155 to equal share and 60 to social sciences students. Genders and branch distribution of students are given in Table 1.

154 of the students who attended to study are from $9^{\text {th }}, 46$ of them from $10^{\text {th }}, 53$ of them from $11^{\text {th }}$ and 77 of them from $12^{\text {th }}$ grades. $46.7 \%$ of total 330 students are $9^{\text {th }}$ grade students. $13.9 \%$ of students in the working group are from $10^{\text {th }}$ grade, $16.1 \%$ of them from $11^{\text {th }}$ grade and $23.3 \%$ of them are from $12^{\text {th }}$ grade. Distribution of students due to their grades is given in Table 2.

Examining the educational status of the parents of students who attended to study, 175 of the mothers are graduated from elementary school, 26 of them from high school, 95 from high school and 33 of them are graduated from universities. For the fathers of the students, 103 of them are graduated from elementary school, 45 of them are graduated from secondary school, 105 of them from high schools and 76 of them graduated from university. Distribution of students due to their parents' educational status is given in Table 3.

\subsection{Data Collection Tool}

In this study, a scale developed by Ugulu, Sahin, \& Baslar (2013) (see Appendix) was used in order to determine environmental attitudes of students. As a result of validity and reliability analysis of this study on scale, it is observed that the scale has 4 dimensions. Considering the results taken from the teacher candidates of the working

Table 1. Frequency and percentages of the group as total due to gender and branches.

\begin{tabular}{cccccccccc}
\hline \multirow{2}{*}{ Gender } & \multicolumn{2}{c}{ Sciences-mathematics } & \multicolumn{2}{c}{ Equal share } & \multicolumn{2}{c}{ Social sciences } & \multicolumn{2}{c}{ TOTAL } \\
\cline { 2 - 9 } & $\mathrm{f}$ & $\%$ & $\mathrm{f}$ & $\%$ & $\mathrm{f}$ & $\%$ & $\mathrm{f}$ & $\%$ \\
\hline Female & 60 & 18.2 & 89 & 27.0 & 36 & 10.9 & 185 & 56.1 \\
Male & 55 & 16.7 & 66 & 20.0 & 24 & 7.3 & 145 & 43.9 \\
TOTAL & 115 & 34.8 & 155 & 47.0 & 60 & 18.2 & 330 & 100.0 \\
\hline
\end{tabular}

Table 2. Frequency and percentage due to grades.

\begin{tabular}{|c|c|c|c|c|c|}
\hline & \multicolumn{4}{|c|}{ Grades } & \multirow{2}{*}{ TOTAL } \\
\hline & $9^{\text {th }}$ grade & $10^{\text {th }}$ grade & $11^{\text {th }}$ grade & $12^{\text {th }}$ grade & \\
\hline $\mathrm{f}$ & 154 & 46 & 53 & 77 & 330 \\
\hline$\%$ & 46.7 & 13.9 & 16.1 & 23.3 & 100.0 \\
\hline
\end{tabular}


Table 3. Frequency and percentage due to parents’ educational status.

\begin{tabular}{cccccccccccc}
\hline & \multicolumn{2}{c}{ Elementary school } & \multicolumn{2}{c}{ Secondary school } & \multicolumn{2}{c}{ High school } & \multicolumn{2}{c}{ University } & \multicolumn{2}{c}{ TOTAL } \\
\cline { 2 - 11 } & $\mathrm{f}$ & $\%$ & $\mathrm{f}$ & $\%$ & $\mathrm{f}$ & $\%$ & $\mathrm{f}$ & $\%$ & $\mathrm{f}$ & $\%$ \\
\hline Mother & 175 & 53.0 & 26 & 7.9 & 95 & 28.8 & 33 & 10.0 & 329 & 99.7 \\
Father & 103 & 31.2 & 45 & 13.6 & 105 & 31.8 & 76 & 23.1 & 329 & 99.7 \\
\hline
\end{tabular}

group, concurrency among the items of these four dimensions is rechecked and it is observed that Cronbach's alfa reliability coefficient of "Environmental Awareness" sub-dimension (15 items) is 0.82, reliability coefficient of “Attitude Towards Recovery” sub-dimension (8 items) is 0.76, reliability coefficient of "Environmental Information and Behavior” sub-dimension (7 items) is 0.75 and reliability coefficient of “Attitude towards recycling” sub-dimension (5 items) is 0.66 . As a result of reliability work for the whole scale, Cronbach's alpha reliability coefficient of scale is determined as 0.80 . In the scale composed of total 35 items, participants are asked to evaluate themselves over four Likert type scale changing from 1 = I do not agree and 4 = I agree. Besides, on the personal information form part of the test, there are questions of independent variables such as participants' names, surnames, genders and grades.

\subsection{Analysis of Data}

Data gathered from execution of Environmental Attitude Scale are tested with SPSS 17.00 (Statistical Package for the Social Sciences) package program. In order to determine relation between branches of sciences and environmental consciousness, variance analysis (ANOVA) was made. $t$-test was used to analyze whether there was a meaningful relation between genders of students and their environmental consciousness.

\section{Results}

In this section, there are analysis of data gathered by data collecting tools over each of sub problems, findings as a result of these analysis and comments about those findings.

\subsection{Findings on Environmental Attitudes of High School Students}

Determining of environmental attitudes of students of each level of education and variables that affect these attitudes is very important for the sufficiency of environmental education in our country and to correct deficiency in this area. Within the scope of the aims of this study, average points gathered from high school students Environmental Attitude Scale (EAS) and scale's sub-dimensions and statistical analysis of these points are tabled in this section.

The highest score students of the working group may get from the 4 likert type EAS composed of 35 items is determined as 140, as a result of analysis, average attitude score of working group composed of 330 students is found 66.01 (Table 4). This value proves that, according to EAS, student candidates have $47.1 \%$ of positive attitude. Considering students' attitude points and shares, we can say that environmental attitude of high school students are at low level.

Students obtained average 26.90 points from the 15 items that take place in "Environmental Awareness" dimension of EAS sub-dimensions; average 12.02 points from the 8 items of “Attitude towards recovery” dimension; average 11.46 points from the 5 items of “Attitude towards recycling” dimension; average 15.63 points from the 7 items of "Environmental Consciousness and Behavior" dimension (Table 4). When these values are evaluated, the highest attitude points are taken in "Environmental Awareness" and 57\% was taken in "Attitude towards recycling”.

When the averages on environmental attitudes of students due to their grades in school, it is observed that, averages of 9 and $11^{\text {th }}$ grade students are below general average $(X=66.01)$; attitude points of $(X 2=68.43$, X4 $=69.02$ ) 10 and $12^{\text {th }}$ grades are above general average (Table 5). Nevertheless, when attitude points are evaluated due to gender variable, in all grades attitudes of male students are higher comparing with the scores of female students (Table 5).

Evaluating averages of environmental attitudes of students due to branches they think they are good at, aver- 
ages of students attending to sciences-mathematics and social sciences students are under the general average (X $=66.03)$, the average of students attending to equal share classes $(X=68.01)$ are below the general average (Table 6).

Considering the situation of mothers of students that attend to working group, we see that, average of mothers graduated from elementary school is 64.08, secondary school is 6.54, mothers graduated from high school is 67.72 and from university 69.98. For the situation of fathers, average of fathers graduated from elementary school is 64.06; secondary school 68.03, average for fathers' graduated from high school 64.79 and average for the ones graduated from university is 69.07. Considering the environmental attitudes of parents, it is observed that for both genders, parents graduated from university have higher averages comparing with the ones graduated from other schools. It is seen that environmental attitude levels increase as we move from elementary school to university (Table 7).

Table 4. Findings on environmental attitude scale and sub-dimensions.

\begin{tabular}{lcccccc}
\hline \multicolumn{1}{c}{ Sub-dimensions } & N & Number of items & Mean & SD & Max & Min \\
\hline 1-Environmental awareness & 330 & 15 & 26.90 & 6.17 & 49 & 15 \\
2-Attitude toward recovery & 330 & 8 & 12.02 & 3.09 & 31 & 8 \\
3-Attitude toward recycling & 330 & 5 & 11.46 & 3.17 & 20 & 5 \\
4-Environmental consciousness and behavior & 330 & 7 & 15.63 & 4.07 & 28 & 7 \\
TOTAL & 330 & 35 & 66.01 & 12.27 & 103 & 38 \\
\hline
\end{tabular}

Table 5. Environmental attitude levels due to gender and grades.

\begin{tabular}{|c|c|c|c|c|c|c|c|c|c|c|c|c|}
\hline \multirow{3}{*}{ Gender } & \multicolumn{12}{|c|}{ Grades } \\
\hline & \multicolumn{3}{|c|}{$9^{\text {th }}$ grade } & \multicolumn{3}{|c|}{$10^{\text {th }}$ grade } & \multicolumn{3}{|c|}{$11^{\text {th }}$ grade } & \multicolumn{3}{|c|}{$12^{\text {th }}$ grade } \\
\hline & $\mathrm{N}$ & $\mathrm{X}$ & SD & $\mathrm{N}$ & $\mathrm{X}$ & SD & $\mathrm{N}$ & $\mathrm{X}$ & SD & $\mathrm{N}$ & $\mathrm{X}$ & SD \\
\hline Female & 85 & 63.09 & 11.32 & 22 & 64.39 & 8.66 & 38 & 62.84 & 10.77 & 40 & 63.62 & 10.73 \\
\hline Male & 69 & 66.28 & 12.52 & 24 & 71.95 & 11.49 & 15 & 67.18 & 10.25 & 37 & 74.86 & 14.95 \\
\hline TOTAL & 154 & 64.52 & 11.94 & 46 & 68.34 & 10.82 & 53 & 64.07 & 10.71 & 77 & 69.02 & 14.03 \\
\hline
\end{tabular}

Table 6. Environmental attitude levels due to students' branches.

\begin{tabular}{cccc}
\hline Branch & $\mathrm{N}$ & $\mathrm{X}$ & $\mathrm{SD}$ \\
\hline Social sciences & 60 & 64.14 & 9.69 \\
Equal share & 155 & 68.01 & 12.76 \\
Sciences-mathematics & 115 & 64.34 & 12.47 \\
TOTAL & 330 & 66.03 & 12.27 \\
\hline
\end{tabular}

Table 7. Environmental attitude levels due to education of parents.

\begin{tabular}{|c|c|c|c|c|c|c|c|c|}
\hline & \multicolumn{4}{|c|}{ Mothers' education } & \multicolumn{4}{|c|}{ Fathers' education } \\
\hline & $\begin{array}{c}\text { Elementary } \\
\text { school }\end{array}$ & $\begin{array}{c}\text { Secondary } \\
\text { school }\end{array}$ & $\begin{array}{c}\text { High } \\
\text { school }\end{array}$ & University & $\begin{array}{c}\text { Elementary } \\
\text { school }\end{array}$ & $\begin{array}{c}\text { Secondary } \\
\text { school }\end{array}$ & $\begin{array}{c}\text { High } \\
\text { school }\end{array}$ & University \\
\hline $\mathrm{N}$ & 175 & 26 & 95 & 33 & 103 & 45 & 105 & 76 \\
\hline $\mathrm{X}$ & 64.08 & 67.54 & 67.72 & 69.98 & 64.06 & 68.03 & 64.79 & 69.07 \\
\hline SD & 12.06 & 10.27 & 11.87 & 14.40 & 12.07 & 9.87 & 12.39 & 13.06 \\
\hline
\end{tabular}




\subsection{Comparison of Environmental Attitudes Due to Independent Variables}

$t$-test results done with the purpose of top priority comparison of environmental attitude points determined by data obtained from high school students Environmental Attitude Scale (EAS) due to grades, proved that there were statistically meaningful differences considering this variable $(p<.05)$ (Table 8$)$.

Due to the results of this analysis, environmental attitude of male students are higher than the environmental attitude of female students.

For the "environmental awareness" sub-dimension of environmental attitude scale, average attitude points of male students were determined as 28.28, while average attitude points of female students were determined 25.82 . $t$-test analyses executed in order to determine whether there had been statistically meaningful difference of environmental attitudes of male and female students showed that, there was a meaningful difference $(p<.05)$ (Table 9). Attitude levels of male students are higher than female students in "Environmental Awareness" subdimension.

For the "Attitude towards Recovery” sub-dimension of Environmental Attitude Scale, average attitude points of male students were determined 11.96, while average attitude points of female students were calculated 12.07 . $t$-test analyses executed in order to determine whether there had been statistically meaningful difference of environmental attitudes of male and female students towards recovery showed that, there was not a meaningful difference $(p>.05)$ (Table 9).

For the “Attitude toward recycling” sub-dimension, attitude points of male students were determined as 12.33, while attitude points of female students were calculated as 10.77. $t$-test analyses executed in order to determine whether there had been statistically meaningful difference of environmental attitudes of male and female students towards recycling showed that, there was a meaningful difference $(p<.05)$ (Table 9). It is seen that attitude levels of male students.

When averages are examined considering "Environmental Consciousness and Behavior” sub-dimension, average attitude points of male students were determined as 16.92, while average attitude points of female students

Table 8. $t$-test results of total scores gathered from environmental attitude scale due to gender.

\begin{tabular}{|c|c|c|c|c|c|}
\hline Gender & $\mathrm{N}$ & $\mathrm{X}$ & SD & df & sig. \\
\hline Female & 185 & 63.31 & 10.72 & \multirow[b]{2}{*}{328} & \multirow[b]{2}{*}{.000} \\
\hline Male & 145 & 69.50 & 13.23 & & \\
\hline
\end{tabular}

Table 9. Comparison of points gathered from the sub-dimensions of environmental attitude scale with $t$-Test due to gender variable.

\begin{tabular}{|c|c|c|c|c|c|c|}
\hline & Gender & $\mathrm{N}$ & Number of items & Mean & $\mathrm{SD}$ & sig. \\
\hline \multirow{3}{*}{ 1-Environmental awareness } & Male & 145 & & 28.28 & 6.53 & \multirow{3}{*}{.000} \\
\hline & Female & 185 & 15 & 25.82 & 5.66 & \\
\hline & TOTAL & 330 & & 26.90 & 6.17 & \\
\hline \multirow{3}{*}{ 2-Attitude toward recovery } & Male & 145 & & 11.96 & 3.07 & \multirow{3}{*}{.752} \\
\hline & Female & 185 & 8 & 12.07 & 3.12 & \\
\hline & TOTAL & 330 & & 12.02 & 3.09 & \\
\hline \multirow{3}{*}{ 3-Attitude toward recycling } & Male & 145 & & 12.33 & 3.38 & \multirow{3}{*}{.000} \\
\hline & Female & 185 & 5 & 10.77 & 2.82 & \\
\hline & TOTAL & 330 & & 11.46 & 3.17 & \\
\hline \multirow{3}{*}{ 4-Environmental consciousness and behavior } & Male & 145 & & 16.92 & 4.43 & \multirow{3}{*}{.000} \\
\hline & Female & 185 & 7 & 14.63 & 3.46 & \\
\hline & TOTAL & 330 & & 15.63 & 4.07 & \\
\hline
\end{tabular}


were calculated as 14.63. $t$-test analyses executed in order to determine whether there had been statistically meaningful difference of environmental attitudes of male and female students on environmental consciousness and behavior showed that, there was a meaningful difference $(p<.05)$ (Table 9). Here also, attitude levels of male students seem higher than the attitudes of female students.

For the results of total points gathered from environmental attitude scale due to grades, a meaningful difference was determined. This difference was determined in favor of $12^{\text {th }}$ grade while comparing $9^{\text {th }}$ and $12^{\text {th }}$ grades and in favor of $12^{\text {th }}$ grade while comparing $11^{\text {th }}$ and $12^{\text {th }}$ grades. $(p<.05)$ (Table 10). It is clearly seen that, total points of the executed environmental attitude scales for $12^{\text {th }}$ grades are higher than the others.

For the "Environmental awareness" sub-dimension of environmental attitude scale, average attitude points of $9^{\text {th }}$ grade was determined $26.75 ; 26.78$ for $10^{\text {th }}$ grade; 25.58 for $11^{\text {th }}$ grade and 28.19 for $12^{\text {th }}$ grades. Difference determined for environmental awareness among students due to their grades was found meaningful $(p>.05)$ (Table 11).

For the "Attitude towards Recovery" sub-dimension of environmental attitude scale, average attitude points of $9^{\text {th }}$ grades were determined as $11.59 ; 12.63$ for $10^{\text {th }}$ grades; 12.28 for $11^{\text {th }}$ grades and 12.34 for $12^{\text {th }}$ grades. Difference of attitudes on recovery among students due to grades were not considered meaningful $(p>.05)$ (Table 11).

When results are examined for the "attitude towards recycling" sub-dimension, average attitude points of $9^{\text {th }}$ grades were calculated as 11.06; attitude points for $10^{\text {th }}$ grades were determined as 12.17 . Average points of $12^{\text {th }}$

Table 10. ANOVA results of total points gathered from environmental attitude scale due to grades.

\begin{tabular}{cccccc}
\hline & Sum of squares & df & Mean square & F & Sig. \\
\hline Within groups & 48046.046 & 326 & 147.381 & 3.362 & .019 \\
Between groups & 1486.666 & 3 & 495.555 & & \\
TOTAL & 49532.713 & 329 & & & \\
\hline
\end{tabular}

Table 11. ANOVA results of sub-dimensions of environmental attitude scale due to grades.

\begin{tabular}{|c|c|c|c|c|c|c|}
\hline & Grades & $\mathrm{N}$ & Mean & $\mathrm{SD}$ & $\mathrm{F}$ & sig. \\
\hline \multirow{4}{*}{ 1-Environmental awareness } & $9^{\text {th }}$ & 154 & 26.75 & 5.82 & \multirow{4}{*}{1.990} & \multirow{4}{*}{.115} \\
\hline & $10^{\text {th }}$ & 46 & 26.78 & 5.49 & & \\
\hline & $11^{\text {th }}$ & 53 & 25.58 & 5.48 & & \\
\hline & $12^{\text {th }}$ & 77 & 28.19 & 7.43 & & \\
\hline \multirow{4}{*}{ 2-Attitude toward recovery } & $9^{\text {th }}$ & 154 & 11.59 & 2.70 & \multirow{4}{*}{1.999} & \multirow{4}{*}{.114} \\
\hline & $10^{\text {th }}$ & 46 & 12.63 & 3.89 & & \\
\hline & $11^{\text {th }}$ & 53 & 12.28 & 2.76 & & \\
\hline & $12^{\text {th }}$ & 77 & 12.34 & 3.44 & & \\
\hline \multirow{4}{*}{ 3-Attitude toward recycling } & $9^{\text {th }}$ & 154 & 11.06 & 3.25 & \multirow{4}{*}{3.136} & \multirow{4}{*}{.026} \\
\hline & $10^{\text {th }}$ & 46 & 12.17 & 3.30 & & \\
\hline & $11^{\text {th }}$ & 53 & 11.01 & 2.59 & & \\
\hline & $12^{\text {th }}$ & 77 & 12.13 & 3.18 & & \\
\hline \multirow{4}{*}{ 4-Environmental consciousness and behavior } & $9^{\text {th }}$ & 154 & 15.10 & 4.33 & \multirow{4}{*}{3.032} & \multirow{4}{*}{.029} \\
\hline & $10^{\text {th }}$ & 46 & 16.74 & 3.73 & & \\
\hline & $11^{\text {th }}$ & 53 & 15.19 & 3.50 & & \\
\hline & $12^{\text {th }}$ & 77 & 16.34 & 3.92 & & \\
\hline
\end{tabular}


grades were calculated as 12.13. Difference was determined in favor of $12^{\text {th }}$ grade while comparing $9^{\text {th }}, 10^{\text {th }}$ and $12^{\text {th }}$ grades; in favor of $12^{\text {th }}$ grade while comparing $11^{\text {th }}$ and $12^{\text {th }}$ grades $(p<.05)$ (Table 11$)$.

Average attitude points of "Environmental Consciousness and Behavior" sub-dimension were calculated as 15.10 for $9^{\text {th }}$ grades, 16.74 for $10^{\text {th }}$ grades, 15.19 for $11^{\text {th }}$ grades and 16.34 for $12^{\text {th }}$ grades. Difference of attitude points due to grades was found meaningful and is examined closely, it was in favor of $12^{\text {th }}$ grades while comparing all $9^{\text {th }}, 10^{\text {th }}$ and $12^{\text {th }}$ grades $(p<.05)$ (Table 11$)$.

When the results of points gathered from environmental attitude scale due to branches of students were examined, difference among attitude points was found meaningful and difference was found in favor of equal share students in comparison between equal share students and students of social sciences and sciences-mathematics ( $p$ $<.05$ ) (Table 12).

For the "Environmental Awareness" sub-dimension of environmental attitude scale composed of 15 items, average attitude points of social sciences students were determined 26.45; average attitude points of equal share students were calculated as 27.73 and average points of sciences-mathematics students were determined as 26.03. There was not any meaningful difference among the attitude points of students due to their branches $(p>.05)$ (Table 13).

For the 8 items of "Attitude towards recovery" sub-dimension of environmental attitude scale, average attitude points of social sciences students were calculated as 11.69; average of equal share students were determined as 12.43; average points of sciences-mathematics students were calculated as 11.65 . Just like environmental awareness dimension, for the attitude towards recovery of students due to their branches, difference was not found meaningful ( $p>$.05) (Table 13).

Examining "Attitude towards recycling" sub-dimension composed of 5 items, average attitude points of social sciences students are 11.04; equal share students are 11.68; sciences-mathematics students are 11.36. No meaningful difference was determined between attitudes of students towards recycling and type of classes they attend to $(p>.05)$ (Table 13).

Table 12. ANOVA results of points gathered from environmental attitude scale due to branches of students.

\begin{tabular}{cccccc}
\hline & Sum of squares & $\mathrm{df}$ & Mean square & F & Sig. \\
\hline Within groups & 48380.691 & 327 & 147.953 & 3.89 & .021 \\
Between groups & 1152.02 & 2 & 576.011 & & \\
TOTAL & 49532.713 & 329 & & \\
\hline
\end{tabular}

Table 13. ANOVA results of environmental attitude scale due to sub-dimensions.

\begin{tabular}{|c|c|c|c|c|c|c|}
\hline & Branch & $\mathrm{N}$ & Mean & $\mathrm{SD}$ & $\mathrm{F}$ & sig. \\
\hline \multirow{3}{*}{ 1-Environmental awareness } & Social sciences & 60 & 26.45 & 5.50 & \multirow{3}{*}{2.709} & \multirow{3}{*}{.068} \\
\hline & Equal share & 155 & 27.73 & 6.28 & & \\
\hline & Sciences-mathematics & 115 & 26.03 & 6.26 & & \\
\hline \multirow{3}{*}{ 2-Attitude toward recovery } & Social sciences & 60 & 11.69 & 2.82 & \multirow{3}{*}{2.531} & \multirow{3}{*}{.081} \\
\hline & Equal share & 155 & 12.43 & 2.94 & & \\
\hline & Sciences-mathematics & 115 & 11.65 & 3.38 & & \\
\hline \multirow{3}{*}{ 3-Attitude toward recycling } & Social sciences & 60 & 11.04 & 2.72 & \multirow{3}{*}{0.963} & \multirow{3}{*}{.383} \\
\hline & Equal share & 155 & 11.68 & 3.13 & & \\
\hline & Sciences-mathematics & 115 & 11.36 & 3.44 & & \\
\hline \multirow{3}{*}{ 4-Environmental consciousness and behavior } & Social sciences & 60 & 14.95 & 3.32 & \multirow{3}{*}{2.598} & \multirow{3}{*}{.076} \\
\hline & Equal share & 155 & 16.16 & 4.09 & & \\
\hline & Sciences-mathematics & 115 & 15.29 & 4.34 & & \\
\hline
\end{tabular}


For the "Environmental consciousness and behavior" sub-dimension composed of last 7 items, average attitude points of social sciences students are 14.95; attitude points of equal share students are 16.16; points of sciences-mathematics students are 15.29. Examining whether there has been a meaningful difference between the branches of students and their attitudes on environmental consciousness and behavior, difference was not considered meaningful ( $p>$.05) (Table 13). Finally, there was not any statistically meaningful difference in $t$-Test results applied to environmental attitude scale sub-dimensions due to the branches of students.

In the environmental attitude scale, a meaningful difference was determined considering education situation of mothers. This difference is in favor of high school in comparison between elementary and high school and in favor of university in comparison between high school and university $(p<.05)$ (Table 14).

Examining the educational status of fathers, there has been a meaningful difference was determined. This difference is in favor of university in comparison between elementary school and university $(p<.05)$ (Table 15).

When attitude points of "Environmental awareness" sub-dimension of environmental attitude scale due to educational status of parents are examined, for the educational status of mothers, average attitude points of mothers graduated from elementary school are 26.25; points are 27.23 for mothers graduated from secondary school; points are 27.61 for the mothers graduated from high school and 28.03 for the mothers graduated from universities. Difference determined was not found meaningful for the educational status of mothers $(p<.05)$ (Table 16).

When the points of “Attitude towards recovery" sub-dimension of environmental attitude scale due to educational status of parents are examined, average attitude points for the mothers graduated from elementary school are 11.86; for the mothers graduated from secondary school are 11.81; for the mothers graduated from high school are 12.25 and for the mothers graduated from university are 12.28. Statistical analyses prove that there has been no meaningful difference considering educational status of mothers ( $p>.05$ ) (Table 16).

Examining attitude points of "Attitude towards recycling” sub-dimension due to educational status of parents, averages of mothers' educational status are as follows: Average attitude points of mothers graduated from elementary school are 10.83; 12.20 for mothers graduated from secondary school; 11.88 for the ones graduated from high schools and 12.84 for the mothers graduated from universities. Different from the other sub-dimensions, in this category, a meaningful difference was determined. Difference is in favor of high school comparing with elementary school and in favor of university comparing with elementary school $(p<.05)$ (Table 16).

For the results of "Environmental Consciousness and behavior" sub-dimension due to educational status of mothers, average attitude points of mothers graduated from are 15.2; for the mothers graduated from secondary school are 16.30; for the mothers graduated from high school are 15.95 and for the mothers graduated from universities are 16.82. No meaningful difference was determined for the educational status of mothers $(p>.05)$ (Table 16).

Considering the educational status of fathers, when the results are examined for the "Environmental Awareness" sub-dimension, average attitude points for the fathers graduated from elementary school are calculated as 26.16; average points for the fathers graduated from secondary school 28.26; average points for the fathers graduated from high school are calculated 26.30 and for the fathers graduated from university are determined as

Table 14. ANOVA results of environmental attitude scale due to mothers' education.

\begin{tabular}{cccccc}
\hline & Sum of squares & $\mathrm{df}$ & Mean square & F & Sig. \\
\hline Within groups & 47877.240 & 325 & 147.315 & 3.421 & .018 \\
Between groups & 1511.874 & 3 & 503.958 & & \\
TOTAL & 49389.115 & 328 & & \\
\hline
\end{tabular}

Table 15. ANOVA results of environmental attitude scale due to fathers' education.

\begin{tabular}{cccc}
\hline & Sum of squares & df & Mean square \\
Within groups & 47947.814 & 325 & 147.532 \\
Between groups & 1441.301 & 3 & 480.434 \\
Total & 49389.115 & 328 & \\
\hline
\end{tabular}


Table 16. ANOVA results of environmental attitude scale sub-dimensions due to mothers' education.

\begin{tabular}{|c|c|c|c|c|c|c|}
\hline & Status of education & $\mathrm{N}$ & Mean & SD & $\mathrm{F}$ & Sig. \\
\hline \multirow{4}{*}{ 1-Environmental awareness } & Elementary school & 175 & 26.25 & 6.13 & \multirow{4}{*}{1.468} & \multirow{4}{*}{.223} \\
\hline & Secondary school & 26 & 27.23 & 5.48 & & \\
\hline & High school & 95 & 27.61 & 6.38 & & \\
\hline & University & 33 & 28.03 & 6.24 & & \\
\hline \multirow{4}{*}{ 2-Attitude toward recovery } & Elementary school & 175 & 11.86 & 3.24 & \multirow{4}{*}{0.445} & \multirow{4}{*}{.721} \\
\hline & Secondary school & 26 & 11.81 & 2.90 & & \\
\hline & High school & 95 & 12.25 & 2.97 & & \\
\hline & University & 33 & 12.28 & 2.83 & & \\
\hline \multirow{4}{*}{ 3-Attitude toward recycling } & Elementary school & 175 & 10.83 & 3.07 & \multirow{4}{*}{5.613} & \multirow{4}{*}{.001} \\
\hline & Secondary school & 26 & 12.20 & 3.31 & & \\
\hline & High school & 95 & 11.88 & 3.02 & & \\
\hline & University & 33 & 12.84 & 3.38 & & \\
\hline \multirow{4}{*}{ 4-Environmental consciousness and behavior } & Elementary school & 175 & 15.12 & 3.97 & \multirow{4}{*}{2.295} & \multirow{4}{*}{.078} \\
\hline & Secondary school & 26 & 16.30 & 3.67 & & \\
\hline & High school & 95 & 15.95 & 3.87 & & \\
\hline & University & 33 & 16.82 & 5.11 & & \\
\hline
\end{tabular}

27.92. It is not possible to speak about a meaningful difference for the educational status of fathers $(p>.05)$ (Table 17).

For the points gathered from "Attitude towards recovery" sub-dimension, average attitude points for the ones graduated from elementary school are 11.81; points are 12.45 for secondary school; 11.82 for the ones graduated from high school and 12.28 for the ones graduated from university. Difference was not found meaningful for the educational status of fathers $(p>.05)$ (Table 17).

When points gathered from "Attitude toward recycling" sub-dimension of environmental attitude scale due to educational status of parents are evaluated, attitude points for the fathers graduated from elementary school are 11.01; average points for the fathers graduated from secondary school are 11.60; average points for the fathers graduated from $\mathrm{d}$ school are 11.35 and for the fathers graduated from university are 12.07. Just like the sub-dimensions mentioned above, it is not necessary to speak about a meaningful difference for the educational status of fathers $(p>.05)$ (Table 17).

Examining the results of points for "Environmental Consciousness and Behavior" sub-dimension of environmental attitude scale due to educational status of parents, average attitude points for the fathers graduated from elementary school are 15.07; for the fathers graduated from secondary school are 15.70; for the fathers graduated from high school are 15.70 and for the ones graduated from university are 16.78. Difference in this category is considered meaningful and difference is in favor of university in a comparison between elementary school and university $(p>$.05) (Table 17).

\section{Discussion and Conclusion}

In this study, the researcher aims to determine the attitudes of biology teacher candidates who will carry a huge responsibility for environmental education and also to compare these attitudes with variables such as education levels, gender. Thus, Environmental Attitude Scale (EAS) with four likert type composed of 35 items which was developed by Ugulu, Sahin, \& Baslar (2013) was used as data gathering tool. Due to the results of study, considering the analyses of data, there are statistically meaningful differences in the environmental attitudes of students for the variables such as gender, grade and educational status of parents and for the variable of education branch, 
Table 17. ANOVA results of sub-dimensions of environmental attitudes due to fathers' education.

\begin{tabular}{|c|c|c|c|c|c|c|}
\hline & Status of education & $\mathrm{N}$ & Mean & $\mathrm{SD}$ & $\mathrm{F}$ & Sig. \\
\hline \multirow{4}{*}{ 1-Environmental awareness } & Elementary school & 103 & 26.16 & 5.93 & \multirow{4}{*}{2.271} & \multirow{4}{*}{.080} \\
\hline & Secondary school & 45 & 28.26 & 5.30 & & \\
\hline & High school & 105 & 26.30 & 5.86 & & \\
\hline & University & 76 & 27.92 & 7.19 & & \\
\hline \multirow{4}{*}{ 2-Attitude toward recovery } & Elementary school & 103 & 11.81 & 2.96 & \multirow{4}{*}{.762} & \multirow{4}{*}{.516} \\
\hline & Secondary school & 45 & 12.45 & 2.82 & & \\
\hline & High school & 105 & 11.82 & 3.33 & & \\
\hline & University & 76 & 12.28 & 3.10 & & \\
\hline \multirow{4}{*}{ 3-Attitude toward recycling } & Elementary school & 103 & 11.01 & 2.95 & \multirow{4}{*}{1.708} & \multirow{4}{*}{.165} \\
\hline & Secondary school & 45 & 11.60 & 3.18 & & \\
\hline & High school & 105 & 11.35 & 3.46 & & \\
\hline & University & 76 & 12.07 & 2.98 & & \\
\hline \multirow{4}{*}{ 4-Environmental consciousness and behavior } & Elementary school & 103 & 1507 & 4.17 & \multirow{4}{*}{2.959} & \multirow{4}{*}{.032} \\
\hline & Secondary school & 45 & 15.70 & 3.72 & & \\
\hline & High school & 105 & 15.30 & 4.22 & & \\
\hline & University & 76 & 16.78 & 3.77 & & \\
\hline
\end{tabular}

there is no meaningful difference. In their "Environmental Attitudes of Biology Teacher Candidates and Examining Several Variables” titled study, Ugulu \& Erkol (2013), examined environmental attitudes of biology teacher candidates. In their study, they used Environmental Attitude Scale (EAS) as data collecting tool. Results of $t$-Test, which was executed in order to compare attitude points due to gender for data gathered from the study including 142 biology teacher candidates proved that there was not any statistically meaningful difference in environmental attitude points $(p>.05)$.

No statistically meaningful difference was determined due to gender for sub-dimensions "Environmental Awareness", Attitude Towards Recovery", "Attitude Towards Recycling” and "Environmental Consciousness and Behavior" $(p>.05)$. In this study, $t$-Test results applied in order to determine whether there has been a statistically meaningful difference in environmental attitude points proved that, there was a meaningful difference in favor of male students $(p<.05)$. In this aspect, this study differs from study of Ugulu \& Erkol (2013). Meanwhile, this study also determined statistically meaningful difference in favor of male students in sub-dimensions such as "Environmental Awareness", "Attitude Towards Recycling" and "Environmental Consciousness and Behavior" $(p<.05)$. On the other hand, both studies come up with the same conclusion in not having a meaningful statistically difference in "Attitude towards recovery" sub-dimension. In our study, when points determined from environmental attitude scale are examined due to grade levels, it is seen that there has been a statistically meaningful difference in attitude points $(p<.05)$. In this aspect, our study differs from that study. When gathered points are examined in environmental attitude scale for each of sub-dimensions, results of attitude points which have statistically meaningful difference in "Environmental Awareness" and "Attitude towards recovery" sub-dimensions are in accordance with that study of Ugulu \& Erkol (2013). But the results of environmental attitude points of "Attitude towards recycling" and "Environmental Consciousness and Behavior" sub-dimensions, do not coincide with the results of that study.

In his "Information Levels of $7-8^{\text {th }}$ Grades Students of Elementary Schools on Environmental Education" titled study, Armagan (2006) reached to some conclusions by comparing data gathered with screening method due to grades and gender in order to determine which grades and gender are more successful. In the study, environmental education test composed of 24 questions was used as data collecting tool. 212 students of 7 and $8^{\text {th }}$ 
grades attended to this study. In that study it was seen that $7^{\text {th }}$ grade students gave more correct answers than the students of $8^{\text {th }}$ grade. Those findings do not coincide with the results of this study. In our study, the level of consciousness increases as the grades go up. Also, finding of no meaningful difference among the results of male and female students does not match with the results of our study.

Ak (2008), in "Evaluation of Environmental Consciousness of Elementary School Teacher Candidates due to Demographic Variables" titled research composed of total 256 participants 146 of which were female and 110 were male, examined whether environmental consciousness of teacher candidates changed due to gender by using screening method. Considering the results of environmental attitude scale as a whole, no meaningful difference was determined due to gender. But, the fact that in some of sub-dimensions consciousness levels of male participants were higher than female teacher candidates is in harmony with the results of our study.

In his "Determining of Consciousness Levels of High School Students on Environmental Education and Solid Waste" titled study, Mert (2006) worked with total of 1341 students, chosen from the various districts of Ankara, 461 of which attended to $9^{\text {th }}, 480$ of which attended to $10^{\text {th }}$ and 400 of which attended to $11^{\text {th }}$ grades. Students were applied information test, also sensitivity test in order to determine their levels of sensitivity. Results of this study proved that, information levels of students on environmental education and solid waste had differences and this difference was in favor of female students, although environmental sensitivity had no difference due to gender. Findings of that study in terms of grade levels coincide with the result of our study. On the other hand, the fact that there had not been a meaningful relation between the education levels of mothers and information level of students on environmental education differs from our study. More, meaningful relation between educational status of fathers and information levels of students on environment coincides with our study. Students, whose fathers are graduated from universities, have higher information levels.

In his "Views of Elementary 4 and $5^{\text {th }}$ Grades Students on Environmental Problems" titled study, Ozpınar (2009) worked with total of 1002 students. In this study, he worked with general screening model and qualitative and quantitative data collecting tools were used. Views of students on environmental problems have meaningful differences considering gender. In our study, this difference is in favor of female students. Considering the results of this study, in terms of educational status of parents, results are in parallel with our study.

Gur (2009), in "Determining of Environmental Consciousness Development Levels of $8^{\text {th }}$ Grade Elementary School Students" named study, tried to evaluate environmental consciousness levels of $8^{\text {th }}$ grade elementary school students and environmental education given in social sciences lectures and importance attributed to environmental education. Study proved that female students had more environmental consciousness than male students. That study does not coincide with the results of our study in this aspect. In our study, consciousness levels of male students are higher than female students.

In their "Evaluation of Environmental Attitudes of High School Students Due to Gender" titled study, Kaya, Ak1lli, \& Sezek (2009), examined the environmental attitudes of high school students due to gender. Prepared "Environmental Attitude Scale” was applied to 450 high school students. Results were evaluated by using SPSS program. In the study, it was determined that, female students had better environmental attitudes. But also it was determined that, students did not transfer their thoughts into actions. That study differs from our study considering gender.

Kesicioglu \& Alisinanoglu (2009), tried to examine the environmental attitudes of pre-school period children in their "Evaluation of Environmental Attitudes of 60 - 72 month Children". The study was executed with 353 children. "Environmental Reaction Inventory" was used as data collecting tool and data were analyzed with SPSS program. Result proved meaningful difference considering gender variable. Meaningful difference was found higher in males for their attitudes towards natural elements. Different from many other studies, results of this study coincide with our study. On the other hand, study determined no meaningful difference in terms of educational status of parents for the environmental attitudes of children, our study determined a difference in favor of parents graduated from universities. With this aspect, study contradicts with our research.

In their "Evaluation of Environmental Attitudes of University Students with Environmental Paradigm and Self Respect Scale” named research, Sam, Sam, \& Ongen (2010) had examined whether there had been a relation between environmental attitudes of university students and self-respect. The research was executed with 398 volunteer university students. The participants were applied a questionnaire composed of social demographic questions aiming to determine information on taking environmental education, economic status of family, age, gender, grade with New Environmental Paradigm Scale and Self Respect Scale. At the end of the study, it was determined that, environmental focused attitude levels of female students were higher than the male stu- 
dents. Considering gender variable, this study differs from our study.

Ozdemir (2010), examined the views of teacher candidates on global warming in his "Examining the Views of Biology and Science Teacher Candidates on Global Warming” titled study. Due to the results of this study, views of teacher candidates on global warming did not include any meaningful difference due to gender and education branch variables. This study does not have any differences on gender basis while our study has differences in favor of male students.

Senyurt, Temel, \& Ozkahraman (2011), in their "Evaluating of Environmental Sensitivity of University Students" named study, tried to answer the question "Which social and demographic factors determine environmental attitudes of university students?" 250 university students attended to the study. "Environmental Attitude Scale” and "Social Demographic Questionnaire Form” were used as data collecting tools. In students' attitudes towards environment, gender, branch of education and previously taken environmental education had important roles. Comparing with our study, this research shows positive attitude of female students. Considering educational status of mothers, this study does not coincide with our study. While this study does not foresee any meaningful difference for educational status of mothers, our study determines a meaningful difference in favor of high school in comparison between elementary and high schools and in favor of university between elementary school and university.

Ozgen (2012), examined the environmental attitudes of university students in his "Environmental Attitudes of Candidate Teachers: Turkey Example" titled study. The study was executed with 727 candidate teachers from elementary school programs of 8 different Turkish universities. Data were collected with personal information questionnaire and environmental attitude questionnaire scales. Method in this study was a definitional screening model, which aimed to determine differences of environmental attitudes of teacher candidates due to level of their grades, main branches, and functional characteristics of their residences variables. Due to independent variables, both for 3 categories, environmental attitudes of teacher candidates had meaningful differences. For the gender variable, meaningful difference is in favor of female teacher candidates. Like in many other studies, this study too differs from our study in this aspect. Our study determines that female participants have more advanced attitude comparing with female participants.

Aydın \& Cepni (2012), in their "Evaluation of Environmental Attitudes of Elemantary School Second Phase Students within the Scope of Some Variables" titled study, worked with 790 students. They used previously developed "Environmental Attitude Scale" for data collecting tool. It was determined that students had positive attitudes towards environment. Considering gender variable, results of this study coincide with our research. In order words, the meaningful differences in both studies are in favor of male students. On the other hand, attitude points due to grade levels gave opposite results. For instance; it is interesting that results are in favor of 6th grades in comparison between 6th and 8th grades; and in favor of 7th grades while comparing with 8th. However, in our study, attitude points go higher as the level of grades increase. Both studies differ from one another also for the educational status of mothers.

Degirmenci (2013), in the "Evaluation of Environmental Attitudes of Elementary School Students within the Scope of Several Variables" titled study, aimed to examine environmental attitudes of elementary school students due to different variables. The research includes total of 114 elementary school students from 6th, 7th and 8th grades. Environmental attitude scale, which was applied to students was composed of 4 sub-dimensions which were increase of population, energy savings, environmental problems and nuclear energy. Furthermore, some variables such as gender, grade, previously taken environmental education and educational status of mothers were also tried to be determined. Results were evaluated with SPSS program. As a result, the meaningful difference considering gender was in favor of female students. with this aspect, our study differs from the results of that research. on the other hand, both studies coincide in terms of grade variable. Both studies prove that, as the level of grade increase, so the environmental attitude does. Again, both studies are in harmony considering the educational status of mothers. Students, whose mothers are graduated from universities, have higher environmental attitudes.

Ocal (2013), in a study named "Determining the Attitudes of Social Sciences Teacher Candidates", studied on environmental attitudes of 455 social sciences teacher candidates considering a series of variables. For data collecting tools, Environmental Attitude Scale developed by Şama (2003) and personal information forms were used. Results of this study showed that, teacher candidates were interested in environmental issues. Considering gender, again as in many other studies, results were in favor of female teacher candidates. In this study, no meaningful difference was observed as grades increased and from this perspective, study differs from our research. Another contradicting variable is that, in this study, students whose mothers are graduated from elementary 
schools have higher environmental attitudes. Again, no meaningful difference was observed in this study for the educational status of fathers and this too, does not coincide with our work.

Gurbuz, Cakmak, \& Derman (2013), in their "Attitudes of Biology Teacher Candidates towards Sustainable Environment" study, tried to determine the environmental attitudes of students in the light of several variables such as gender, grades and information sources for environment. The study was executed with 152 biology students. In the study, in which screening method was used, data were analyzed by using SPSS program. When data were analyzed with $t$-Test technique, it was determined that in some of the sub-dimensions, attitudes of teacher candidates are high. Also differences were calculated for the variables like gender, level of grades and source of information. This study differs from our research since it determines positive attitudes in favor of female students, while both studies give parallel results considering levels of grades.

\section{References}

Ak, S. (2008). İlköğretim Öğretmen Adaylarının Çevreye Yönelik Bilinçlerinin Bazı Demografik Değişkenler Açısından Incelenmesi. Bolu: Yüksek Lisans Tezi, Abant İzzet Baysal Universitesi, Sosyal Bilimler Enstitüsü. [Investigation of Elementary School Pre-Service Teachers' Consciousness toward Environment in Terms of Some Demographic Variables. Unpublished M.Sc. Thesis, Bolu: Abant Izzet Baysal University, Institute of Social Sciences.]

Altın, M. (2001). Biyoloji Öğretmeni Adaylarında Çevre Ĕgitimi. Ankara: Yüksek lisans tezi, Gazi Universitesi, Fen Bilimleri Enstitüsü. [Environmental Education in Biology Pre-Service Teachers. Unpublished M.Sc. Thesis, Ankara: Gazi University, Institut of Sciences.]

Armagan, F. O. (2006). İlköğretim 7. ve 8. Sinıf Öğrencilerinin Çevre Eğitimi ile ilgili Bilgi Düzeyleri (Kırıkkale İl Merkezi Örneklemi), Yüksek Lisans Tezi. Ankara: Gazi Universitesi. [ $7^{\text {th }}$ and $8^{\text {th }}$ Grades Students' Knowledge Levels about Environmental Education. Unpublished M.Sc. Thesis, Ankara: Gazi University, Institute of Sciences.]

Aydın, F., \& Cepni, O. (2012). İlköğretim İkinci Kademe Öğrencilerinin Çevreye Yönelik Tutumlarının Bazı Değişkenler Açısından İncelenmesi (Karabük İli Örneği). Dicle Universitesi Ziya Gökalp Eğitim Fakültesi Dergisi, 18, 189-207. [Investigation of Elementary School Students' Attitudes toward Environment in Terms of Some Variables. Journal of Dicle University Ziya Gokalp Faculty of Education, 18, 189-207.]

Bahar, M. (2000). Universite Öğrencilerinin Çevre Ĕ̈itimi Konularındaki Ön Bilgi Düzeyi, Kavram Yanılgıları (poster), V. Uluslar arası Ekoloji ve Çevre Sorunları Sempozyumu, Ankara: TÜBİTAK. [University Students' Pre-Conceptions about Topics of Environmental Education, V. International Symposium on Ecology and Environmental Problems, Ankara: TUBITAK.]

Bradley, J. C., Waliczek, T. M., \& Zajicek, J. M. (1999). Relationship between Environmental Knowledge and Environmental Attitude of Light School Students. The Journal of Environmental Education, 30, 17-21. http://dx.doi.org/10.1080/00958969909601873

Degirmenci, M. (2013). İlköğretim Öğrencilerinin Çevreye Karşı Tutumlarının Farklı Değişkenler Açısından İncelenmesi (Kayseri İli Örneği). Middle Eastern \& African Journal Educational Research, 3, 59-68. [Investigation of Elementary School Students' Attitudes toward Environment in Terms of Different Variables. Middle Eastern \& African Journal Educational Research, 3, 59-68.]

Dincer, C. (1999). Okul Öncesi Dönem Çocuklarının Çevresel Farkındalıklarını Artırma Yolları. Çevre ve İnsan Dergisi, 44, Ankara: T.C. Çevre Bakanlığı Yayını. [Ways Improve of Pre-School Students' Environmental Awareness. Journal of Environment and Human, 44, Ankara: Republic of Turkey Ministry of Environment Press.]

Dogan, M. (1997). Ulusal çevre eylem planı: Eğitim ve katılım. DPT: Türkiye Çevre Vakfı. [National Environmental Action Plan: Education and Participation. Turkish Environment Foundation.]

Erol, G. H. (2005). Sınıf Öğretmenliği İkinci Sınıf Öğrencilerinin Çevre ve Çevre Sorunlarına Yönelik Tutumları. Yüksek Lisans Tezi, Denizli: Pamukkale Universitesi. [Elementary School Pre-Service Teachers' Attitudes toward Environment and Environmental Problems. Unpublished M.Sc. Thesis, Denizli: Pamukkale University, Institute of Sciences.]

Erol, G., \& Gezer, K. (2006). Sınıf Öğretmenliği Öğretmen Adaylarına Çevreye ve Çevre Sorunlarına Yönelik Tutumları. International Journal of Environmental and Science Education, 1, 65-77. [Elementary School Pre-Service Teachers' Attitudes toward Environment and Environmental Problems. International Journal of Environmental and Science Education, 1, 65-77.]

Geray, C. (1995). Çevre Koruma Bilinci ve Duyarlılığı İçin Halkın Eğitimi. Yeni Türkiye Çevre Özel Sayısı, TemmuzAğustos. [Public Education for Environmental Consciousness and Sensitivity. New Turkey: Environment Special Issue, July-August.]

Gunduz, T. (2004). Çevre Sorunları. Ankara: Gazi Kitabevi. [Environmental Problems. Ankara: Gazi Kitabevi Press.]

Gur, K. (2009). İlköğretim sekinci sınıf öğrencilerinin çevre bilinci düzeylerinin belirlenmesi. Yüksek lisans tezi, Balıkesir: Sosyal Bilimler Enstitüsü, Balıkesir Universitesi. [Determination of 8th Grades Students’ Environmental Consciousness. 
Unpublished M.Sc. Thesis, Balikesir: Institute of Social Sciences, Balikesir University.]

Gurbuz, H., Cakmak, M., \& Dermen, M. (2013). Biyoloji Öğretmen Adaylarının Sürdürülebilir Çevreye Yönelik Tutumları. Türk Bilimsel Derlemeler Dergisi, 6, 144-149. [Biology Pre-Service Teachers’ Attitudes toward Sustainable Environment. Turkish Journal of Scientific Reviews, 6, 144-149.]

Karasar, N. (2005). Bilimsel Araştırma Yöntemleri (14. Bask1). Ankara: Nobel Yayınları. [Scientific Research Methods (14th ed.). Ankara: Nobel Yayinlari Press.]

Kaya, E., Akıllı, M., \& Sezek, F. (2009). Lise Öğrencilerinin Çevreye Karşı Tutumlarının Cinsiyet Açısından İncelenmesi. Mehmet Akif Ersoy Universitesi Ĕ̌itim Fakültesi Dergisi, 18, 43-54. [Investigation of High School Students' Attitudes toward Environment in Terms of Gender. Journal of Mehmet Akif Ersoy University Faculty of Education, 18, 43-54.]

Kesicioglu, O. K., \& Alisinanoglu, F. (2009). 60-72 Aylık Çocukların Çevreye Karşı Tutumlarının Çeşitli Değişkenler Açısından İncelenmesi. Ahi Evran Universitesi Eğitim Fakültesi Dergisi, 10, 37-48. [60-72 Months Childs' Attitudes toward Environment in Terms of Some Variables. Journal of Ahi Evran University Faculty of Education, 10, 37-48.]

Mert, M. (2006). Lise Öğrencilerinin Çevre Ĕ̆itimi ve Kati Atıklar Konusundaki Bilinç Düzeylerinin Saptanması. Yayımlanmamış Yüksek Lisans Tezi, Ankara: Fen Bilimleri Enstitüsü, Hacettepe Universitesi. [Determination of High School Students' Consciousness about Environmental Education and Solid Wastes. Unpublished M.Sc. Thesis, Ankara: Institute of Sciences, Hacettepe University.]

Ocal, T. (2013). Sosyal Bilgiler Öğretmen Adaylarının Çevre Sorunlarına Yönelik Tutumlarının Belirlenmesi. Marmara Cografya Dergisi, 27, 333-352. [Determination of Social Sciences Pre-Service Teachers' Attitudes toward Environmental Problems. Marmara Geography Journal, 27, 333-352.]

Ozdemir, C. (2010). Biyoloji ve Fen Bilgisi ögrretmen adaylarının küresel ısınma konusundaki görüşlerinin bazı değişkenler açısından incelenmesi. Yüksek Lisans Tezi, Ankara: Eğitim Bilimleri Enstitüsü, Gazi Universitesi. [Investigation of Biology and Sciences Pre-Service Teachers' Opinions about Global Warming in Terms of Some Variables. Unpublished M.Sc. Thesis, Ankara: Institute of Education Sciences, Gazi University.]

Ozgen, N. (2012). Öğretmen Adaylarının Çevre Sorunlarına Yönelik Tutumları: Türkiye Örneği. Kastamonu Eğitim Dergisi, 20, 403-422. [Pre-Service Teachers' Attitudes toward Environmental Problems: Example of Turkey. Kastamonu Education Journal, 20, 403-422.]

Ozpınar, D. (2009). İlköğretim 4. ve 5. Sınıf Öğrencilerinin Çevre Sorunları Hakkındaki Görüşleri (Afyonkarahisar İli Örneği). Yayımlanmamış Yüksek Lisans Tezi, Afyonkarahisar: Sosyal Bilimler Enstitüsü, Afyon Kocatepe Universitesi. [4th and 5th Grades Students' Opinions about Environmental Problems. Unpublished M.Sc. Thesis, Afyonkarahisar: Institut of Social Sciences, Afyon Kocatepe University.]

Sam, N., Sam, R., \& Ongen, K. B. (2010). Universite Öğrencilerinin Çevresel Tutumlarının Yeni Çevresel Paradigma ve Benlik Saygısı Ölçeği ile İncelenmesi. Akademik Barış Dergisi, 21, 1-16. [Investigation of University Students’ Environmental Attitudes Using New Ecologic Paradigm and Self-Esteem Scale. Academic Peace Journal, 21, 1-16.]

Senyurt, A., Temel, B. A., \& Ozkahraman, S. (2011). Universite Öğrencilerinin Çevresel Konulara Duyarlılıklarının İncelenmesi. S.D. U. Sa ğlık Bilimleri Enstitü Dergisi, 2, 8-23. [Investigation of University Students' Sensitivity on Environmental Topics. Journal of SDU Institute of Health Sciences, 2, 8-23.]

Ugulu, I. (2011). The Impact of Recycling Education on the Knowledge, Attitudes and Behaviors of Secondary School Students. PhD Thesis, Izmir: Dokuz Eylul University.

Ugulu, I., \& Erkol, S. (2013). Biyoloji öğretmen adaylarının çevreye yönelik tutumları ve çeşitli değişkenler açısından incelenmesi. NWSA-Education Sciences, 8, 79-89. [Investigation of Biology Pre-Service Teachers' Attitudes toward Environment in Terms of Some Variables. NWSA-Education Sciences, 8, 79-89.]

Ugulu, I., Aydın, H., Yorek, N., \& Dogan, Y. (2008). The Impact of Endemism Concept on Environmental Attitudes of Secondary School Students. Natura Montenegrina, 7, 165-173.

Ugulu, I., Sahin, M., \& Baslar S. (2013). High School Students’ Environmental Attitude: Scale Development and Validation. International Journal of Educational Sciences, 5, 415-424.

Uzun, N., \& Saglam, N. (2006). Orta öğretimde Öğrenciler İçin Çevresel Tutum Ölçeği Geliştirme ve Geçerliliği. Hacettepe Universitesi Ĕ̈itim Fakültesi Dergisi, 30, 240-250. [Environmental Attitude Scale Development and Validation for Secondary School Students. Journal of Hacettepe University Faculty of Education, 30, 240-250.]

Yılmaz, A., Morgil, I., Aktug, P., \& Gobekli, I. (2002). Ortaöğretim ve Universite Öğrencilerinin Çevre, Çevre kavramları ve Sorunlar1 Konusundaki Bilgileri ve Öneriler. Hacettepe Universitesi Eğitim Fakültesi Dergisi, 22, 156-162. [University and High School Students' Knowledge about Environment, Environmental Concepts and Environmental Problems and Recommendations. Journal of Hacettepe University Faculty of Education, 22, 156-162.]

Yumlu, K. (1998). Basın ve Çevre (Bildiri), Kuşadası Beledivesi II Kıyı Sorunları ve Çevre Sempozyumu, 14-16 Kasım 1997. Aydin: Kuşadası Belediyesi Yayını. [Kusadasi Municipality II Symposium on Coastal Problems and Environment, 14-16 November 1997. Aydin: Kusadasi Belediyesi Press.] 


\section{Appendix: Items and Factor Structures of the Environmental Attitude Scale (EAS)}

\section{Factor I (Environmental Awareness)}

The primary purpose of tree planting is to beautify the environment in terms of aesthetics

Since the environment can clean itself, human waste does not cause a problem.

Instead of spending money on historical places, it is more advantageous for us to build luxurious roads.

Some species are unnecessary for the environment.

The government should give permission for building, on touristic purpose, in national parks and forests.

The media news about polluted seas, rivers and lakes are exaggerated.

The extinction of the insects such as flies is useful for environment.

Nature renews itself with substance cycle. Therefore, recycling helps economy only in terms of time.

The best way to build houses is to dry up the wetlands and build there.

I do not think that recycling works as much as it is said.

It is meaningless to buy paper bags instead of nylon bags given for free in the markets.

People have the right to make changes in nature for meeting their needs.

A land does not have desertification problem if it is surrounded on three sides by sea

Money can be saved by buying drinks in plastic bottles since drinks in glass bottles are expensive.

I am curious about how the natural events occur.

Factor II (Attitudes towards recovery)

Using rechargeable batteries instead of disposable batteries supports recycling.

Giving old clothes to the people in need supports recycling.

We should throw the used batteries and bottles into the appropriate trash bins.

Using old newspapers for packing supports recycling.

Shopping only as much as needed is an important step in recycling.

I believe that we should be economical for environment.

We should use both sides of white papers to support recycling.

For saving energy, I turn off the lights in my house when they are not used.

\section{Factor III (Attitudes towards recycling)}

I can go from door to door to teach people recycling.

I separate waste materials in my house for recycling.

I feel sad when I a see people throwing away objects that can be recycled.

When I buy a product I pay attention whether its case is recyclable.

It makes me happy when people recycle used bottles, cans and paper.

Factor IV (Environmental Consciousness and Behavior)

For a livable environment, I can work voluntarily for a long time if needed.

I do not waste water while I am brushing my teeth.

I prefer environmentally harmless products even if they are more expensive.

I participate in environmental projects.

My friends know me as a sensible person towards environment.

I talk with people around me on environmental matters.

I can reutilize the back sides of used papers if possible. 